\title{
ВПЛИВ КОРПОРАТИВНОЇ КУЛЬТУРИ НА ДІЯЛЬНІСТЬ ПІДПРИЕМСТВА
}

\author{
Гриценко Н.В., к.е.н., доцент (УкрДУЗТ)
}

У даній статті розглянуто вплив сучасної корпоративної культури на підприємство. Теоретично розглянуто, що вона представляє сукупність моделей поведінки, які придбані підприємством в процесі його функиіонування. Обтрунтовано, що високий рівень корпоративної культури виступає ключовим фактором довгострокової ефективності функиіонування підприємства, за рахунок впливу на мотивацію прачівників, продуктивність й ефективність їхньої трудової діяльності. Визначено, щзо корпоративна культура є комплексом елементів підприємства, спрямованих на формування сприятливого мікроклімату, іміджу, які трунтуються на системі иінностей працівників з метою досягнення ними максимальних показників ефективності роботи. Корпоративна культура є системою особистих і колективних иінностей, які сприймаються і поділяються членами підприємства, а також набір прийомів і правил вирімення проблем зовнішньої адаптащії та внутрішньої інтеграції працівників, щуо виправдали себе в минулому й підтвердили свою актуальність сьогодні.

Ключові слова. корпоративна культура, діяльність підприємств, персонал, кар'єра, управлінське рішення.

\section{ВЛИЯНИЕ КОРПОРАТИВНОЙ КУЛЬТУРЫ НА ДЕЯТЕЛЬНОСТЬ ПРЕДПРИЯТИЯ}

\author{
Гриценко Н.В., к.э.н., доцент (УкрГУЖТ)
}

В даной статье рассмотрено влияние современной корпоративной культуры на предприятие. Теоретически рассмотрено, что она представляет собой совокупность моделей поведения, которые приобретенны предприятием в процессе его функционирования. Обосновано, что высокий уровень корпоративной культурь выступает ключевым фактором долгосрочной эффективности функционирования предприятия, за счет воздействия на мотивацию работников, производительность и эффективность их трудовой деятельности. Определено, что корпоративная культура представляет собой комплекс элементов предприятия, которые выделяют ее среди других, направленные на формирование благоприятного микроклимата, имиджа и основываются на системе иенностей работников с иелью достижения ими максимальных показателей эффективности работы. Корпоративная культура является системой личных и коллективных ценностей, которые воспринимаются и разделяются членами предприятия, а также набор приемов и правил решения проблем внешней адаптации и внутренней интеграџии работников, оправдавщих себя в прошлом и подтвердивших свою актуальность сегодня.

Ключевые слова: корпоративная культура, деятельность предприятий, персонал, карьера, управленческое решение. 


\title{
THE INFLUENCE OF CORPORATE CULTURE ON THE ACTIVITY OF THE ENTERPRISE
}

\author{
Gritsenko N.V., Candidate of Economic Sciences, Associate Professor \\ (Ukrainian State University of Railway Transport)
}

This article examines the impact of modern corporate culture on the enterprise. Theoretically, it is considered that it is a set of behaviour patterns that are acquired by the enterprise in the process of its functioning. It is substantiated that a high level of corporate culture is a key factor in the long-term efficiency of the enterprise's functioning, due to influence on motivation of employees, productivity and efficiency of their labour activity. Corporate culture is a complex of elements of the enterprise that distinguish it among others, aimed at creating a favorable microclimate, image and are based on the value system of employees in order to achieve their maximum performance indicators. Corporate culture is an important factor in the development of the company's internal potential. It is proved that, recently, the influence of corporate culture on the activities of enterprises is an important element, since it affects the increase of its labor potential. And the increase in labor potential leads to an increase in the competence of personnel, which in general leads to profitability of the whole enterprise. Corporate culture is a system of personal and collective values that are perceived and shared by the members of the enterprise, as well as a set of techniques and rules for solving the problem of external adaptation and internal integration of workers who have justified themselves in the past and confirmed their relevance today. Summarizing the above definitions, we can conclude that corporate culture is a system of values, beliefs, beliefs, ideas, expectations, symbols, as well as the operating principles, norms of behavior, traditions, rituals, etc. that have developed in the organization or its divisions during the activity and accepted by the majority of employees. decision.

Key words: corporate culture, enterprise activity, personnel, career, managerial

Постановка завдання дослідження. На протязі останнього часу науковцями розглядаються питання впливу корпоративної культури на діяльність підприємств. Корпоративна культура $\epsilon$ важливим чинником у розвитку внутрішнього потенціалу підприємства.

Економіка зможе успішно розвиватися завдяки енергетиці культури як певної системи цінностей, норм поведінки, моралі. Корпоративна культура за допомогою своїх внутрішніх сил робить будь-яке підприємство життєздатним та успішним.

Актуальність даної теми випливає 3 необхідності створення відповідної концепції формування корпоративної культури підприємства як основи його сталого розвитку в майбутньому. Важливою умовою такого розвитку $\epsilon$ науково-теоретичний огляд основних ознак впливу корпоративної культури на підприємство, що визначає ii базові вихідні, засади. В умовах забезпечення економічного i соціального розвитку вивчення принципів корпоративної культури обумовлене важливістю їі впливу на діяльність підприємства. Принципи корпоративної культури повинні відповідати критеріям стабільного та ефективного розвитку підприємства. Впровадження та дотримання принципів корпоративної культури дозволить зробити iii могутнім інструментом управління персоналом, забезпечить цілісність підприємства, створить сприятливі умови для управління підприємством та сприятиме стабільному розвитку корпоративної культури.

Аналіз досліджень і публікацій. 
Дослідженням корпоративної культури, як важливого чинника управління персоналом займається велика кількість наукових діячів, таких як Аніщенко В.О. [1], Бала О.Л., Мукан Р.Д. [2], Гриценко Н.В. [3,4], Химич Г.О. [5], Чернишова Т.О. [6]. Проте дане питання сьогодні тільки набирає оберти, так як, невід'ємно зв'язане 3 мінливими зовнішніми змінами, чим більше викликає інтерес науковців в цій галузі. Тому, можна стверджувати, що питання вивчення корпоративної культури і надалі залишається актуальним.

Метою даного дослідження $\epsilon$ теоретичний огляд матеріалу щодо обгрунтування показників впливу корпоративної культури на успішну ділову активність підприємства.

Виклад основного матеріалу. Корпоративна культура $\epsilon$ парадигмою бізнесу, що орієнтована на людські потреби й інтереси, врахування їх в господарській практиці підприємства. При цьому, сама сфера потреб та інтересів людини, що працює на підприємстві, істотно розширюється. Працівника розглядають як члена певного співтовариства, соціальної групи, колективу 3 властивими йому цінностями та правилами поведінки.

Зростаюче значення людини в діяльності підприємства призводить до усвідомлення того, що воно $є$ не тільки організацією, яка націлена на отримання прибутку, а й співтовариством людей 3 їхніми між особистими відносинами, від яких залежить успішність роботи підприємства. Ключовим поняттям при визначенні суті корпоративної культури $\epsilon$ людське середовище, тобто вона $\epsilon$ продуктом взаємодії:

- підприємства як організації;

- співробітників підприємства, 3 їхніми особистими інтересами й потребами;

- колективу в цілому та окремих групах у межах організації;

- зовнішнього середовища, 3 його вимогами до діяльності підприємства.
Всі інтереси, потреби, цілі, що існують на підприємстві, під впливом людського фактора формують корпоративну культуру.

Кожне успішне підприємство має свою корпоративну культуру - це сукупність найважливіших положень його діяльності. Ці положення обумовлені місією та стратегією розвитку, та знаходять своє відображення в соціальних нормах $\mathrm{i}$ цінностях більшості працівників. Така культура створює атмосферу ідентифікованості для іiі членів, зміцнює соціальну стабільність та є контролюючим механізмом, який направляє i формує відносини та поведінку працівників.

Ефективна корпоративна культура має велике значення для підприємства. Поперше, корпоративна культура надає працівникам корпоративної ідентичності, визначає внутрішньогрупове уявлення про підприємство, є важливим джерелом стабільності і наступності. Це створює у працівників почуття надійності підприємства і свого місця в ній, соціальної захищеності. По-друге, знання цінностей, норм i правил, які сформувалися на підприємстві, допомагають новим працівникам правильно інтерпретувати події, що відбуваються в ній, і відповідно визначити свою поведінку. По-третє, корпоративна культура більше, ніж щось інше, стимулює самосвідомість і високу відповідальність працівника, що виконує поставлені перед ним завдання. Механізми впливу корпоративної культури на діяльність підприємства полягають у тому, що працівники прогнозують розвиток ситуації, щодо якої, керуючись цінностями, оцінюють і вибудовують моделі своєї поведінки та спілкування [3].

Вплив корпоративної культури на ділову активність підприємства має різноплановий характер i може проявлятися через: процеси, структуру, систему відносин. Основними ознаками впливу корпоративної культури на успішну діяльність підприємств є:

- побудова простої організаційної 
структури на підприємстві;

- гнучкість в управлінні;

- дотримання гуманістичних

цінностей серед працівників;

- соціальне спрямування діяльності;

персоналу;

$$
\text { підтримка самореалізації }
$$

креативності.

Для забезпечення успішної

діяльності підприємства воно повинно володіти адаптаційними властивостями пристосування до умов зовнішнього середовища, можливостями досягнення поставленої мети, і бути цілісною, добре структурованою системою. Цього можна досягти завдяки наявності рис, які притаманні корпоративній культурі підприємства. Дані риси виокремлюють найважливіші функції корпоративної культури, а саме: функція формування корпоративних цінностей; формування позитивного іміджу підприємства; розвиток прогресивних соціально-трудових відносин; консолідуюча функція корпоративної культури; створення єдиного культурного простору.

Головне полягає у тому, що ці функції, а точніше, їхня ефективна реалізація залежить від вибору пріоритетних напрямів формування інтелектуального капіталу підприємства. Якщо персонал поділяє думку керівництва щодо адаптації, досягнення мети та інших аспектів організаційної ефективності, підприємство зможе стати успішним. Можна у цьому зв'язку згадувати про соціальні аспекти цієї моделі, оскільки лише інтелектуально розвинений працівник може зрозуміти завдання, які стоять перед підприємством.

Існують різні підходи до визначення набору змінних, використання яких дозволяе виявити вплив корпоративної культури підприємства на його діяльність (рис.1).

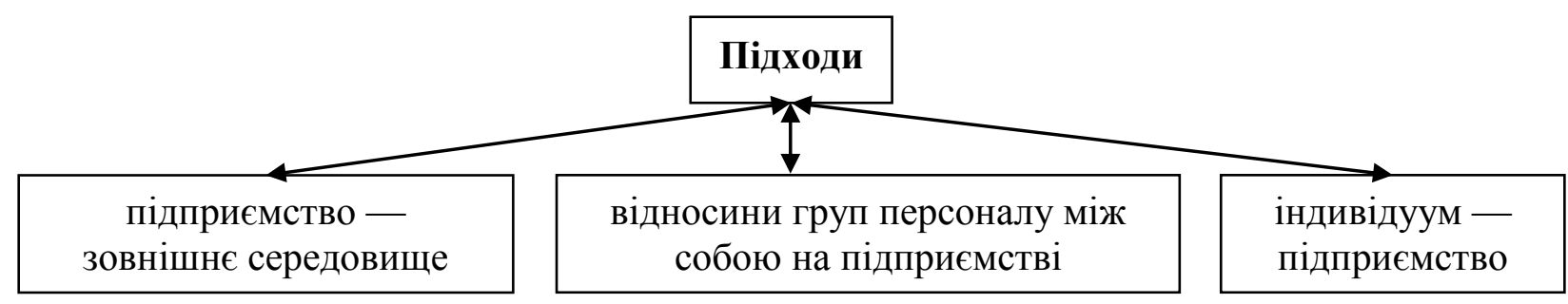

Рис.1. Підходи до визначення набору змінних впливу на корпоративну культуру

Причому для кожного рівня індивідуума, їх угрупування, підприємства - можна вимірювати як ефективність їх функціонування 3 позицій інтересів підприємства, так і задоволеність працівників. Крім того, кожну із змінних можна розглядати як у короткостроковому періоді, так і на перспективу.

Дану модель розробив Т. Парсонс, проте, вона складна для практичного застосування [2].
Ідеї Т. Парсонса знайшли своє продовження в дослідженнях Р. Куїнна та Дж. Рорбаха, які запропонували свою модель під назвою "Конкуруючі цінності і організаційна ефективність" $[1,2]$. Суть моделі зводиться до того, що вПлив корпоративної культури розглядається через призму вимірювань, названих конкуруючими цінностями. Ця модель має такі складові подані на рис. 2 . 


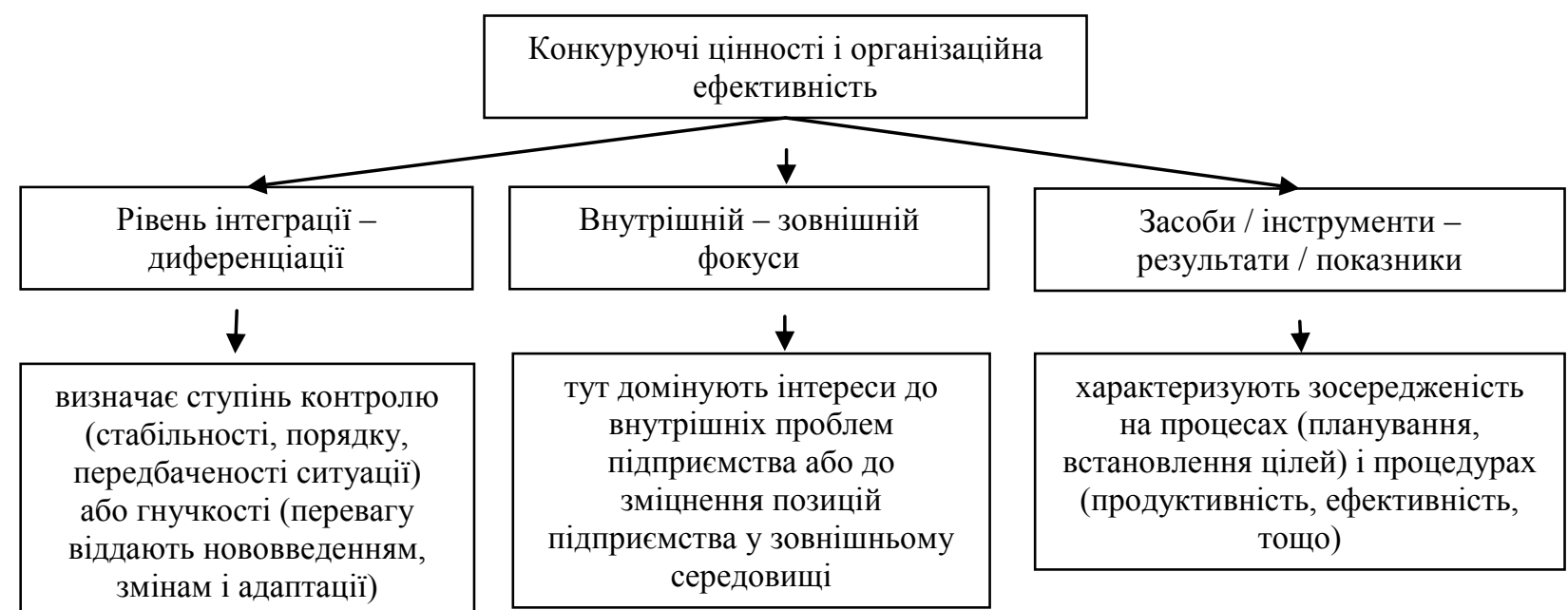

Рис.2. Схема моделі Р. Куӥнна та Дю. Рорбаха

Наведена модель визначає цінності організаційної культури підприємства у тісному зв'язку 3 кожним підходом до визначення ефективності i зіставляє перспективу одного підходу 3 усіма іншими. Досягнення певного рівня ефективності діяльності господарюючого суб'єкта зумовлено поширеністю практики застосування нематеріальних активів, використання й розвитку професійних даних працівників, зміцнення стосунків зі споживачами. Це входить до складу інтелектуального капіталу.

Керівництво

повинно використовувати корпоративну культуру підприємства як могутній інструмент його лідерства. Її високий рівень дає можливість управляти за допомогою норм і цінностей, а не шляхом безпосереднього впливу на працівників. Причому можна швидко приймати рішення на місцях, чітко визначати стандарти якості, критерії само оцінок і легше розуміти орієнтованість на споживачів.

Науковці виділять чотири рівні результативності діяльності підприємства:

- результати першого рівня - кінцеві результати діяльності підприємства;

- результати другого рівня характеристики кінцевого продукту, створеного підприємством;

- результати третього рівня характеристики ефективності процесу створення кінцевого продукту;
- результати четвертого рівня характеристики раціонального формування і розвитку самого підприємства.

Корпоративна культура $є$ п'ятим, фундаментальним рівнем, основою всієї решти рівнів [3].

Корпоративна культура впливає на всі чотири рівні, оскільки результати діяльності визначаються орієнтирами діяльності і цінностями. Характеристики кінцевого продукту також залежать від корпоративної культури: якщо вона зорієнтована на споживача, то буде створений продукт, що відповідає попиту; корпоративна культура встановлює пріоритети у властивостях продукту (висока якість, низька ціна i т.д.). Ефективність процесу створення кінцевого продукту залежить від ефективності використання потенціалу підприємства, яка, також, визначається цінностями i орієнтирами діяльності. Раціональність формування $\mathrm{i}$ розвитку самого підприємства буде зростати із зростанням орієнтації потенціалу підприємства на максимізацію кінцевих результатів іiі діяльності.

Наведені вище моделі впливу корпоративної культури на діяльність підприємства мають важливе наукове i практичне значення, оскільки підтверджують роль корпоративної культури в розвитку ділової активності підприємства 
Корпоративна культура впливає на конкурентоспроможність підприємства, що проявляється у формуванні позитивної репутації, привабливого іміджу та продукту (товару або послуг) серед споживачів, ділових партнерів, інвесторів, кредиторів та інших представників суспільства. Корпоративна культура, орієнтована на інновації, зміцнюючи трудовий потенціал працівників, формує інтелектуальну власність підприємства, що також підвищує його конкурентоспроможність завдяки наявності унікальних розробок, технологій, інноваційної продукції. Отже, корпоративна культура $\epsilon$ внутрішнім джерелом стимулювання інноваційної активності підприємств.

В умовах інформаційно інтелектуального суспільства стрімко зростає кількість науковомістких сфер діяльності, інтелектуалізація праці, прагнення до саморозвитку й удосконалення. Сутність цих процесів відображається в корпоративній культурі, i, зокрема, в іiі різновиді - інноваційній культурі. Інноваційна культура передбачає використання новітніх технологій та інтелектуалізації праці [1,4]. Корпоративна культура створює внутрішню базу підприємства, сприяє згуртованості колективу, формує у співробітників почуття відповідальності за свою роботу. Корпоративна культура підвищує ефективність роботи працівників і вирішує задачі, як індивідуального розвитку співробітників, так і розвитку підприємства загалом. Вона створює передумови для формування стійкого i ефективно працюючого колективу, що чітко представляє місію підприємства.

Загалом, процеси, структура, поведінка, рівень конкурентоспроможності підприємства формують загальну результативність іiі діяльності, тому твердження про те, що корпоративна культура впливає на всі характеристики результативності, $\epsilon$ абсолютно обгрунтованою.

Висновок. Отже корпоративна культура має вагомий вплив на діяльність підприємства, i основною іiі метою $\epsilon$ підвищення трудового потенціалу, бо він $\epsilon$ «основою підприємства». Підвищення трудового потенціалу приводить до зростання компетенції персоналу, що означає зростання прибутковості підприємства в цілому. Компетентніші працівники характеризуються креативним мисленням, вони здатні генерувати ідеї i працювати продуктивніше. Усе це позитивно відіб'ється на якості продукції, дозволить підприємству розробляти власні унікальні технології та продукцію, тим самим підвищуючи тим самим загальну ділову активність.

Отже, всі аспекти впливу корпоративної культури на успішну ділову активність підприємства є важливими, а тому можемо говорити про ефективність корпоративної культури загалом. Саме корпоративна культура точно визначає поведінку працівників. Передбачуваність, упорядкованість і послідовність діяльності на підприємстві формується за допомогою високої формалізації. Ефективна корпоративна культура досягає того ж результату без ведення якої-небудь документації. Більше того, вона може бути більш ефективною, ніж будь-який формальний структурний контроль. Чим сильніша культура організації, тим менше управлінському персоналу потрібно приділяти уваги розвитку формальних правил i положень для керування поведінкою працівника.

\section{ПЕРЕЛІК ВИКОРИСТАНИХ ДЖЕРЕЛ}

1. Аніщенко В.О. Роль корпоративної культури у прийнятті управлінських рішень / В.О. Аніщенко //Актуальні проблеми економіки. - 2009. № 3 (93). - С. 64 - 72.

2. Бала О.Л. Принципи корпоративної культури підприємств: сутність та види / О.Л. Бала, О.В. Мукан // 
Вісн. нац. ун-ту "Львів. політехніка". - 2010. 145-149.

- № 682. - С. 11-15.

3. Гриценко Н.В. Особливості формування корпоративної культури організації/ Н.В. Гриценко// Вісник економіки транспорту і промисловості. X.- 2017. - №59. - С. 284-290.

4. Гриценко Н.В. Корпоративна культура як елемент системи управління персоналом/ Н.В. Гриценко// Техн. прогрес і ефект. виробництва - 2018. - №15. - С.

5. Химич Г.О. Модель формування корпоративної культури для машинобудівних підприємств / І.Г. Химич // Держава та регіони. - Сер.: Економіка та підприємництво. - 2010. - № 2. - С. 218-223.

6. Чернишова Т.О. Деякі аспекти корпоративної культури організації / Т.О. Чернишова, Т.А. Немченко // Наукові праці КНТУ. Економічні науки. - 2010. - В. 17. C. $472-485$.

DOI 10.18664/338.47:338.45.v\%vi\%i.133532

\title{
УДК 330.341.1:656.07
}

\section{ФОРМУВАННЯ СТРАТЕГЇ̈ ІНОВАЦЙНОГО РОЗВИТКУ ДЛЯ ПІДПРИЕМСТВ ЗАЛІЗНИЧНОГО ТРАНСПОРТУ В УМОВАХ ФОРМУВАННЯ ВИСОШВИДКІСНОГО РУХУ}

\author{
Дейнека О.Г., д.е.н., професор, \\ Камчатна Ю.С., магістр по програмі ТЕМПУС (УкрДУЗТ)
}

У статті розглянуті особливості формування інновачійної стратегії розвитку підприємств залізничного транспорту в умовах високошвидкісного руху. Проаналізовані основні види інноваційних стратегій, та надані рекомендації, щэодо удосконалення методики ӥх вибору.

Утворення ПАТ «Укрзалізниці» потребує грунтівних досліджень щэодо розиирення та впровадження в практику новітніх розробок.

Це є особливо актуальним в умовах очікуваного формування високошвидкісного pyxy.

Ключові слова: інновації, інноваційна стратегія, конкурентоспроможність, розвиток, аспекти, глобалізація, залізничний транспорт.

\section{ФОРМИРОВАНИЕ СТРАТЕГИИ ИННОВАЦИОННОГО РАЗВИТИЯ ДЛЯ ПРЕДПРИЯТИЙ ЖЕЛЕЗНОДОРОЖНОГО ТРАНСПОРТА В УСЛОВИЯХ ФОРМИРОВАНИЯ ВИСОШВИДКИСНОГО ДВИЖЕНИЯ}

\author{
Дейнека О.Г., д.е.н., професор, \\ Камчатна Ю.С., магистр попрограмме ТЕМПУС (УкрГУЖТ)
}

В статье рассмотрены особенности формирования инновачионной стратегии развития предприятий железнодорожного транспорта в условиях высокоскоростного движения. Проанализированы основные виды инновационных стратегий, и предоставлены рекомендации по совершенствованию методики их выбора.

(C) Дейнека О.Г.,

Камчатна Ю.С.

Вісник економіки транспорту і промисловості № 62, 2018 